\title{
Distribution of peroxisome proliferator-activated receptors (PPARs) in human skeletal muscle and adipose tissue: relation to insulin action
}

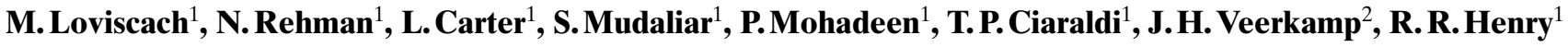 \\ ${ }^{1}$ VA San Diego Healthcare System, San Diego, California, USA \\ ${ }^{2}$ Department of Biochemistry, Catholic University Nijmegen, Nijmegen, The Netherlands
}

\section{Abstract}

Aims/hypothesis. To evaluate the tissue distribution and possible role of the peroxisome proliferator-activated receptors (PPARs) in insulin action in fat and muscle biopsy specimens from lean, obese and subjects with Type II (non-insulin-dependent) diabetes mellitus.

Methods. We measured PPAR $\alpha, \operatorname{PPAR} \beta(\delta)$ and $\operatorname{PPAR} \gamma$ protein expression by western blot analysis. The PPAR $\gamma$ protein was also measured in muscle before and after 3-h hyperinsulinaemic $\left(300 \mathrm{mU} \cdot \mathrm{m}^{-2}\right.$. $\min ^{-1}$ ) euglycaemic clamps.

Results. The PPAR $\alpha$ protein was expressed preferentially in muscle relative to fat (more than sevenfold). The $\operatorname{PPAR} \beta$ protein was similar in fat and muscle. The amount of PPAR $\gamma$ protein found in muscle was, on average, two-thirds of that present in fat. There was no statistically significant difference between non-diabetic and diabetic subjects in baseline (preclamp) muscle PPAR $(\alpha, \beta$ or $\gamma)$ protein expression. Subgroup analysis showed, however, significantly higher PPAR $\gamma$ protein in the most insulin resistant diabetic subjects with glucose disposal rates of $3-6 \mathrm{mg} \cdot \mathrm{kg}^{-1} \cdot \mathrm{min}^{-1}$ compared with their age and weight matched counterparts with glucose disposal rates of $6-9(147 \pm 23$ vs $88 \pm 10 \mathrm{AU} / \mu \mathrm{g}$ protein, $p \leq 0.01$ in diabetic and vs $94 \pm 15, p \leq 0.04$ in non-diabetic subjects). Muscle PPAR $\gamma$ protein and glucose disposal rates were inversely correlated in diabetic subjects $(r=-0.47, p \leq 0.05)$.

Conclusion/interpretation. All PPARs $(\alpha, \beta$ or $\gamma)$ are present in skeletal muscle and adipose tissue with different relative distributions. The PPAR $\gamma$ protein is abundant in skeletal muscle as well as adipose tissue. The altered expression of skeletal muscle PPAR $\gamma$ is consistent with a role for this nuclear protein in the impaired insulin action of Type II diabetes. [Diabetologia (2000) 43: 304-311]

Keywords Type II diabetes, insulin resistance, $\operatorname{PPAR} \alpha, \operatorname{PPAR} \beta, \operatorname{PPAR} \gamma$, protein, obesity, skeletal muscle, adipose tissue, human.
The peroxisome proliferator activated receptors (PPARs) are members of the nuclear receptor superfamily, which are involved in gene regulation $[1,2]$.

Received: 16 August 1999 and in revised form: 18 October 1999

Corresponding author: R.R. Henry MD, VA San Diego Healthcare System (V111G), 3350 La Jolla Village Drive, San Diego, California 92161, USA

Abbreviations: PPAR, Peroxisome proliferator-activated receptor; RXR, retinoid X receptor; ALBP, adipocyte-specific lipid binding protein; $\mathrm{mFABP}$, muscle-specific fatty-acid binding protein; GDR, glucose disposal rate.
The PPAR $\alpha$ protein is expressed in several human tissues, including skeletal muscle, liver, kidney and vascular endothelial cells [3]. It has been suggested that it is involved in the control of lipoprotein metabolism $[4,5]$, fatty acid oxidation $[6,7]$ and the cellular uptake of fatty acids [8]. The transcriptional activity of PPAR $\alpha$ is stimulated by insulin [9], fibrates and the selective agonist 4-chloro-6(2,3-xylidino)-2-pyrimidinyl-thioacetic acid (WY14643). The PPAR $\beta$ (also designated PPAR $\delta$ and NUC1) protein has been found in a number of different tissues in the adult rat [10] but its distribution, regulation and function in human tissue is still to be determined. The last 
of these nuclear receptors, $\operatorname{PPAR} \gamma$, is known to play a critical part in adipocyte differentiation and fat deposition and is highly expressed in this tissue $[1,11]$. The $\operatorname{PPAR} \gamma$ receptor exists as two protein isoforms, $\gamma 1$ and $\gamma 2$, the products of alternative splicing. The PPAR $\gamma 2$ isoform contains an N-terminal 30 aminoacid extension and has a lower mobility on SDSPAGE gel [12]. The $\operatorname{PPAR} \gamma$ receptor is bound to and activated by the natural prostaglandin derivative 15 -deoxy- ${ }^{12,14}$-prostaglandin $\mathbf{J}_{2}[13]$, as well as the synthetic insulin sensitizing thiazolidinediones such as troglitazone, pioglitazone and rosiglitazone [14-19]. A close relation between the ability of different thiazolidinediones to activate PPAR $\gamma$ and their potency as antidiabetic agents supports the importance of PPAR $\gamma$ in the regulation of glucose and lipid metabolism and possibly insulin action [17].

In addition PPAR $\gamma$ mRNA has been identified in skeletal muscle [20-22]; the major site of impaired insulin action in Type II (non-insulin-dependent) diabetes mellitus and obesity. Furthermore, PPAR $\gamma$ mRNA expression has been found to be increased in adipose and muscle tissue of some insulin resistant obese rodents and humans [21-24], further suggesting this receptor is involved in regulation of metabolism and insulin action. Despite its presence in human skeletal muscle, PPAR $\gamma$ mRNA abundance is generally $5 \%$ or less of that in adipose tissue on the basis of total RNA. This discrepancy in mRNA abundance between tissues has led some investigators to minimise or exclude a role for muscle PPAR $\gamma$ in the control of glucose/lipid metabolism in this tissue. Recognition that PPAR $\gamma$ protein, not message, is responsible for its gene effects, has, however, received little attention until recently when specific immunoblotting antibodies for PPAR $\gamma$ protein became available. Recently, immunohistochemistry was used to show that PPAR $\gamma$ protein is present within nuclei of myocytes [25].

In previous studies from our laboratory, $P P A R \gamma$ gene expression (mRNA) in skeletal muscle was found to be rapidly up-regulated in response to insulin treatment in both non-diabetic control and Type II diabetic subjects [22]. In the current report, other than comparing tissue distribution of PPARs in human muscle and fat, we sought to determine PPAR $\alpha$, $\operatorname{PPAR} \beta$ and $\operatorname{PPAR} \gamma$ protein expression in the tissues of subjects with and without Type II diabetes. Further, we evaluated whether metabolic variables such as glucose, insulin or triglycerides, characteristically increased in Type II diabetes, might contribute to any differences in PPAR expression between these groups.

\section{Subjects and methods}

Materials. All radioisotopes were obtained from DuPont-NEN (Boston, Mass., USA). Bovine serum albumin (BSA, fraction $\mathrm{V}$ ) was purchased from Boehringer Mannheim (Indianapolis,
Ind., USA). Reagents for electrophoresis were purchased from Bio-Rad (Richmond, Calif., USA). Polyclonal antibodies for PPAR $\gamma$ were obtained from BioMol (Plymouth Meeting, Pa., USA), for PPAR $\beta$ from Santa Cruz Biotechnology (Santa Cruz, Calif., USA) and for PPAR $\gamma 2$ from Affinity BioReagents (Golden, Colo., USA). A monoclonal antibody generated against the amino terminal region of human PPAR $\alpha$ (residues 2-101) was a gift from Dr. D. A. Winegar at Glaxo Wellcome (Research Triangle Park, N.C., USA). Anti-rabbit and anti-mouse IgG conjugated with horseradish peroxidase were purchased from Amersham (Arlington Heights, Ill., USA). SuperSubstrate chemiluminescence substrate was from Pierce (Rockford, Ill., USA). All other reagents were purchased from Sigma (St. Louis, Mo., USA), as was a monoclonal antibody against $\alpha$-sarcomeric actin.

Subjects. Adipose tissue was obtained from the abdominal region, under lidocaine anaesthesia, using a side-cutting needle [26]. Muscle biopsy specimens were obtained from the vastus lateralis of 22 non-diabetic control subjects without a family history of diabetes and 14 subjects with Type II diabetes before and after a 3 -h hyperinsulinaemic $\left(300 \mathrm{mU} \cdot \mathrm{m}^{-2} \cdot \mathrm{min}^{-1}\right)$ euglycaemic (5.0-5.5 mmol/l) clamp as described in detail previously [27]. Of the subjects with diabetes, seven were treated with oral antidiabetic agents (sulphonylurea, biguanide), three with insulin and four with diet only. None of the subjects was treated with thiazolidinedione agents. Glucose tolerance was determined in all subjects after a 75-g oral glucose tolerance test [28]. Subjects with diabetes had their medication withheld on the morning of biopsy. None of the control subjects were receiving any medications known to influence glucose metabolism. The Committee on Human Investigation of the University of California, San Diego approved the experimental protocol. Informed written consent was obtained from all subjects after explanation of the protocol.

Western blotting of PPAR proteins. Tissue protein lysates were prepared as described previously [29]. Western blot analysis was done by the method of Burnette [30] as detailed previously [29]. Equal amounts of total protein were loaded. Total protein content was determined by a dye-binding method [31]. All blots contained an extract of human adipocytes as an internal standard. The results were normalized to this standard to correct for blot to blot variation. The validity of the PPAR $\gamma$ antibody was established by several criteria. The antibody recognised a doublet of 62000-65000 $\mathrm{M}_{\mathrm{r}}$ in 3T3-L1 adipocytes, the intensity of this band increased considerably upon differentiation from the fibroblast phenotype (Fig.1). A band of similar size was found with another commercially available polyclonal antibody generated in rabbits against human $\operatorname{PPAR} \gamma$ (Santa Cruz Biotechnology, Santa Cruz, Calif., USA). Blocking with a peptide specific for this antibody abolished the detection of this band. The antibody did not recognize overexpressed retinoid X receptor (RXR) $\alpha, \beta$ or $\gamma$ (kind gift of Dr. R. Mukherjee, Ligand Pharmaceuticals, San Diego, Calif., USA), nor PPAR $\alpha$ or $\beta$. The PPAR $\gamma 2$ protein content was determined with a commercially available polyclonal antibody generated in rabbits against a peptide sequence described to be specific for human $\operatorname{PPAR} \gamma 2$ [32]. The secondary antibody for $\operatorname{PPAR} \gamma, \operatorname{PPAR} \gamma 2$, and $\operatorname{PPAR} \beta$ was anti-rabbit IgG conjugated with horseradish peroxidase and a similarly conjugated anti-mouse $\mathrm{IgG}$ was used for PPAR $\alpha$. Muscle biopsy specimen proteins were visualised with SuperSignal, exposed to high performance chemiluminescence film (Hyperfilm ECL, Amersham Life Science, Little Chatfont, England) and quantified with the NIH image software (Bethesda, Md., USA). To rule out possible inaccuracies due to the limited range of linearity of chemiluminescence 
film, all muscle to fat comparisons were also quantified with a low light imaging system (ChemiImager 4000, Alpha Innotech, San Leandro, Calif., USA). Results are presented as 'arbitrary units' of the intensity of the western blot bands as detected by the indicated imaging software. These results are normalised to the value for an internal control sample included on all blots to account for blot-to-blot variation.

For the analysis of other proteins, adipocyte-specific binding protein (ALBP) detection was used with a polyclonal antibody generously provided by Dr. D. Bernlohr (University of Minnesota, USA). Sarcomeric-specific $\alpha$-actin was detected with a monoclonal antibody using a horseradish peroxidase conjugated anti-mouse IgG as the secondary antibody. Muscle tissue content of muscle-specific fatty-acid binding protein (mFABP) was measured by ELISA according to a previously reported method [33].

Northern blot analysis of tissue specific genes. To evaluate the potential adipose tissue content of muscle biopsy specimens, samples were probed for the mRNA of muscle (myogenin and $\mathrm{mFABP}$ ) and adipose ALBP tissue specific genes. From the total RNA $10 \mu \mathrm{g}$ was size-separated by electrophoresis through denaturing formaldehyde $1-1.5 \%$ agarose gel and transferred to a nitrocellulose membrane (Nytran, Schleicher \& Schuell, Keene, N.H., USA). To control for gel loading, the membranes were stained with methylene blue and relative intensities of the ribosomal bands were compared quantitatively using computer imaging (NIH Image). Myogenin and mFABP DNA probes for northern analysis were labelled by the hexamer priming method in the presence of $\alpha{ }^{32} \mathrm{P} d C T P$ using the Ambion DECAprime II Random Priming Kit (Ambion, Austin, Tex., USA). The myogenin probe consisted of a $1.5 \mathrm{~kb}$ EcoR1 fragment from pBS. For the mFABP probe, a $0.5 \mathrm{~kb}$ EcoRI fragment of pSP6.5 containing the cDNA for mFABP was used. Specific antisense RNA probes (riboprobes) for human-ALBP were synthesised from vector pAP2, (gift of Dr. D. Bernlohr, University of Minnesota). Hybridization of DNA and RNA probes was carried out at $68^{\circ} \mathrm{C}$ in $10 \mathrm{ml}$ of QuickHyb (Stratagene, San Diego, Calif., USA) according to the manufacturer's instructions. Relative intensities of transcript signals in the linear range were compared quantitatively using computer imaging (NIH Image). The mRNA for PPAR $\gamma 1,2$ was measured by a quantitative reverse transcriptase-PCR assay, as described previously [22].

Statistical analysis. Statistical significance was evaluated using Student's $t$ test for dependent and for independent samples and regression analysis. Sample sizes were pre-calculated on the basis of the first three western blot results for PPAR $\gamma$ in each group to achieve a statistical power of $95 \%$ or more. Statistical power in the subgroup analysis of severely diabetic subjects compared with moderately diabetic subjects, as classified by glucose disposal rate (GDR) groups, was $80 \%$ or more (StatSoft, STATISTICA, Tulsa, Okla., USA and GraphPad PRISM, San Diego, Calif., USA). Significance was accepted at $p 0.05$ or less.

\section{Results}

Subjects. Clinical characteristics (Table 1) showed fasting concentrations of blood glucose, serum insulin and $\mathrm{HbA}_{1 \mathrm{c}}$ values all significantly higher in the subjects with Type II diabetes than in the non-diabetic subjects without a family history of diabetes. The glu-
Table 1. Clinical characteristics of the study groups

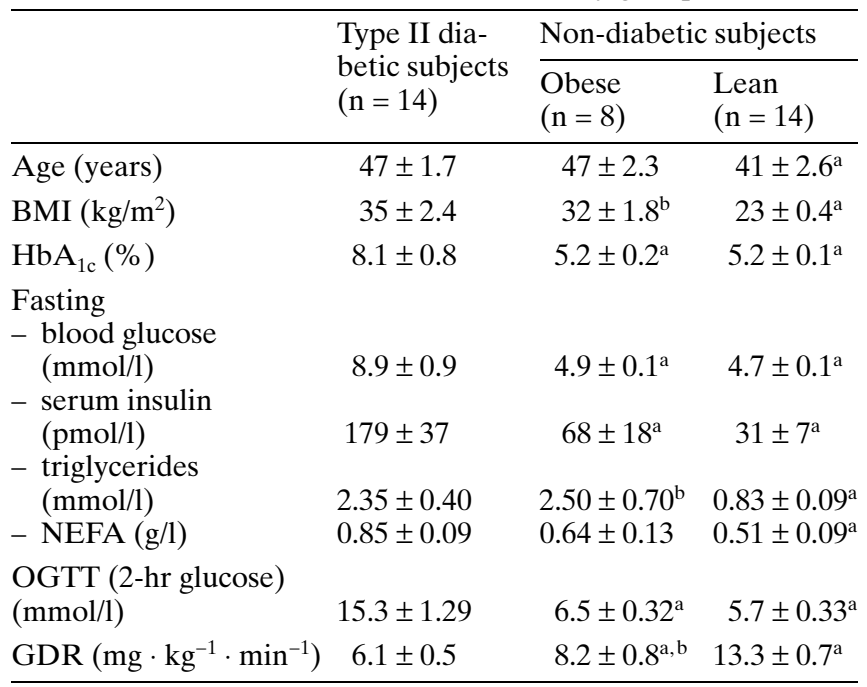

Results are means \pm SEM, ${ }^{\text {a }}$ signifies $p \leq 0.05$ vs Type II diabetic subjects and ${ }^{\mathrm{b}} p \leq 0.05$ vs lean, non-diabetic subjects

Table 2. Baseline protein expression

\begin{tabular}{|c|c|c|}
\hline & $\begin{array}{l}\text { Type II diabetic } \\
\text { subjects }\end{array}$ & $\begin{array}{l}\text { Non-diabetic } \\
\text { subjects }\end{array}$ \\
\hline PPAR $\alpha$ (AU/ $\mu g$ protein) & $100 \pm 13(n=14)$ & $104 \pm 13(n=22)$ \\
\hline 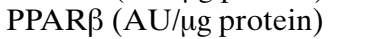 & $114(n=8)$ & $58(n=14)$ \\
\hline 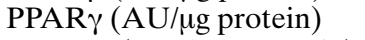 & $113 \pm 13(n=14)$ & $108 \pm 11(n=22)$ \\
\hline $\mathrm{mFABP}(\mathrm{pmol} / \mathrm{mg}$ protein $)$ & $270 \pm 31(n=13)$ & $285 \pm 24(n=20)$ \\
\hline 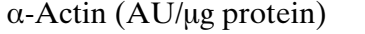 & $233 \pm 46(n=14)$ & $295 \pm 30(n=21)$ \\
\hline
\end{tabular}

Results are given as arbitrary units (AU), number of subjects are given in brackets $(n)$

cose and insulin responses to an oral glucose load were also higher in the diabetes group. Insulin resistance was confirmed in the diabetes group by a significantly reduced maximum insulin-stimulated glucose disposal rate.

Baseline expression of PPARs. All three known PPAR forms are present in appreciable amounts in skeletal muscle (Fig. 2). The PPAR $\alpha$ protein expression was consistently greater in muscle than in adipose tissue from the same subject (five to ninefold of the value in paired fat tissue, on average 7.6-fold). Although displaying considerable intersubject variability, $\operatorname{PPAR} \beta$ protein was detected at approximately the same abundance in both tissues. The PPAR $\gamma$ protein was readily detected in muscle tissue, although the relative expression between muscle and fat $(31-100 \%$ of the value in paired fat, average $=69 \%$, $n=8$ ) varied over a broad range between subjects. The relative expression of PPAR $\gamma$ protein in fat and muscle was similar in non-diabetic and diabetic subjects. The PPAR $\gamma 2$ protein was detectable in fat but not in muscle tissue (Fig. 1). Thus PPAR $\gamma 1$ seems to be the predominant isoform expressed in skeletal 


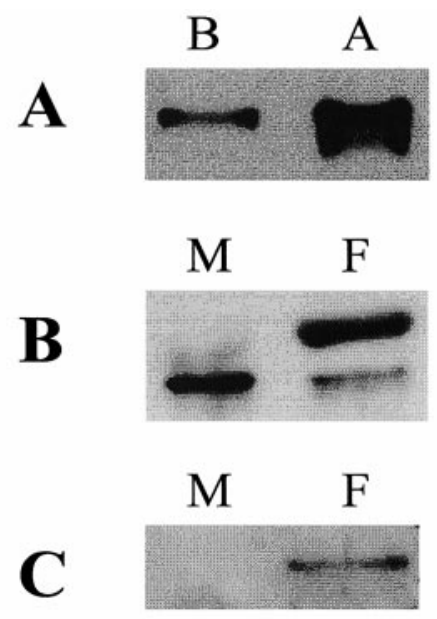

Fig.1A-C. Representative western blots for $\mathbf{A} \operatorname{PPAR} \gamma$ in NIH3T3 cells before (B) and after differentiation into adipocytes (A), B total PPAR $\gamma$ and $\mathbf{C P P A R} \gamma 2$ in muscle (M) and fat $(\mathrm{F})$

muscle. This could also explain why the $\operatorname{PPAR} \gamma$ band detected in muscle consistently displays a greater mobility than that in fat, which seems to contain both PPAR $\gamma 1$ and the larger $\gamma 2$ isoform. (Fig. 2). Electrophoresis conditions were selected to permit analysis of multiple proteins on the same membrane. Under other conditions a doublet for PPAR $\gamma$ was observed in adipose tissue samples (Fig. 1).

No difference in muscle PPAR $\alpha, \beta$ or $\gamma$ protein expression was observed between non-diabetic and Type II diabetic subjects (Table 2). The relative expression of PPAR $\gamma$ mRNA and protein was similar in muscle tissue with significant correlations between PPAR $\gamma$ protein and mRNA in both non-diabetic $(r=0.61, p \leq 0.05)$ and Type II diabetic $(r=0.80$, $p \leq 0.05)$ groups.

Protein expression of muscle-specific fatty acidbinding protein (mFABP), which is known to be critical for utilisation of cellular fatty acids, and of $\alpha$-sarcomeric actin, a marker for the muscle phenotype [34] was also similar in both groups (Table 2). Human adipose lipid binding protein (hALBP) mRNA and protein were detectable in adipose but not muscle tissue, consistent with minimal adipose content of muscle samples.

Regulation of baseline PPAR expression. To determine whether the in vivo metabolic environment might influence the expression of the PPARs in muscle, the relations between protein expression of these nuclear receptors and clinical characteristics were investigated. Regression analysis showed no influence of age, BMI, fasting serum lipids (non-esterified fatty acids and triglycerides), blood glucose, glycated haemoglobin and fasting serum insulin on protein expression of any PPAR in the whole study group or the diabetic and non-diabetic groups individually. Be-
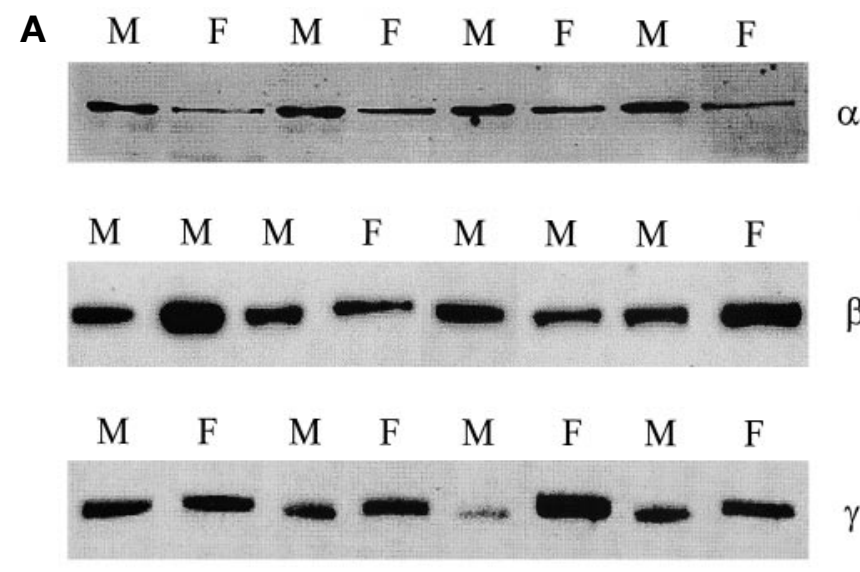

B

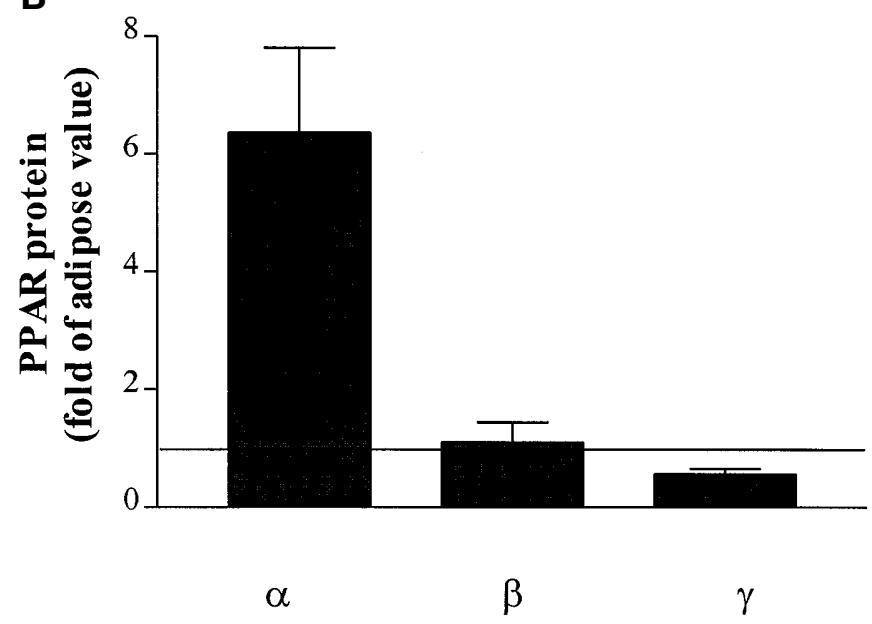

Fig. 2. A Expression of PPAR $\alpha$ (top panel), $\operatorname{PPAR} \beta$ (middle panel) and PPAR $\gamma$ (bottom panel) proteins in human skeletal muscle and isolated adipocytes. Tissue was obtained and protein extracts prepared as described in the Methods section. Equal amounts $(10 \mu \mathrm{g})$ of muscle $(\mathrm{M})$ and adipocyte $(\mathrm{F})$ protein were separated by SDS-PAGE and western blotted by antisera against $\operatorname{PPAR} \alpha, \operatorname{PPAR} \beta$ and $\operatorname{PPAR} \gamma$. For $\operatorname{PPAR} \alpha$ and $\operatorname{PPAR} \gamma$, tissues from the same subject were run in adjacent lanes. B Relative expression of PPAR protein in skeletal muscle. Results presented as a fold of the expression in adipocytes from the same subjects. Average $\pm \operatorname{SEM}$ for $\operatorname{PPAR} \alpha(n=5)$, $\operatorname{PPAR} \beta(n=6), \operatorname{PPAR} \gamma(n=8)$

cause PPAR $\gamma$ protein has been suggested as being involved in the regulation of skeletal muscle insulin action, the relation between these two variables was explored further. The insulin-stimulated GDR, determined in each subject during the last $30 \mathrm{~min}$ of a hyperinsulinaemic $\left(300 \mathrm{mU} \cdot \mathrm{m}^{-2} \cdot \mathrm{min}^{-1}\right)$, euglycaemic clamp, was used as a measure of maximum insulin action in muscle. A statistically significant inverse relation was detected between muscle $\operatorname{PPAR} \gamma$ protein and maximum GDR in the diabetic subjects $(r=-0.47, p \leq 0.05)$. Conversely, in the non-diabetic subjects, there was a trend for PPAR $\gamma$ protein to increase with increasing GDR (Fig. 3A), the opposite of the behaviour observed in diabetic subjects, 

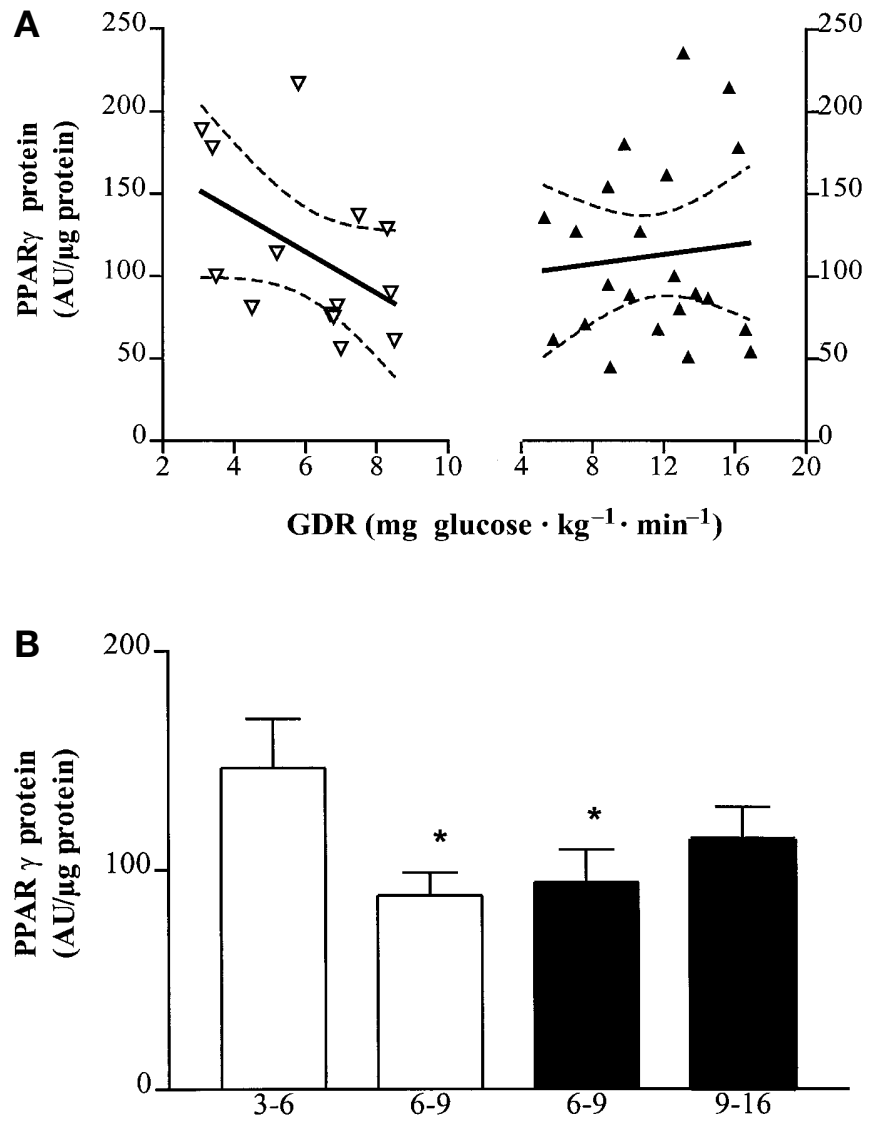

GDR (mg glucose $\cdot \mathbf{k g}^{-1} \cdot \mathbf{m i n}^{-1}$ )

Fig.3A, B. Expression of PPAR $\gamma$ protein as a function of maximum insulin action (insulin-stimulated GDR). A Correlation of PPAR $\gamma$ protein and GDR in diabetic $(r=0.47, p \leq 0.05$, $\Delta)$ and non-diabetic (not significant, $\boldsymbol{\Delta}$ ) subjects. B Non-diabetic ( $\square$ ) and Type II diabetic $(\square)$ subjects grouped by GDR. Muscle biopsy specimens obtained before insulin infusion. Average \pm SEM. $* p \leq 0.05$ vs GDR $=3-6$

though this correlation did not attain statistical significance. Diabetic subjects with severe insulin resistance $\left(\mathrm{GDR}=3-6 \mathrm{mg} \cdot \mathrm{kg}^{-1} \cdot \min\right.$, mean $\left.=4.3, n=6\right)$ were compared to diabetic subjects with moderate to mild resistance $($ GDR $=6-9$, mean $=7.5, n=8)$ and to non-diabetic subjects with low $(\mathrm{GDR}=6-9$, mean $=7.5, n=7)$ and high $($ GDR $=9-16$, mean = 13.3, $n=15)$ insulin responsiveness. This subgroup analysis showed significantly higher muscle PPAR $\gamma$ protein in diabetic subjects with severe insulin resistance (GDR = 3-6) compared with their diabetic counterparts matched with them for age and weight with moderate to mild resistance ( $147 \pm 23$ vs $88 \pm 10$ AU/ $\mu$ g protein, $p \leq 0.01)$ and non-diabetic subjects $(147 \pm 23$ vs $94 \pm 15, p \leq 0.04)$ with GDR $=6-9$ (Fig.3B). Thus, the most insulin resistant diabetic subjects have the highest muscle PPAR $\gamma$ protein expression. Except for the lean non-diabetic subjects, the subgroups were matched for BMI, eliminating obesity as a variable. Age, BMI, non-esterified fatty acids, fasting glucose, glycated haemoglobin and fasting insulin did not differ between the two diabetic subgroups with GDR $=3-6$ and GDR $=6-9$. The PPAR $\alpha, \beta, \mathrm{mFABP}$ and $\alpha$-sarcomeric actin protein also did not differ between the four GDR subgroups (not shown).

Short-term effect on insulin on protein expression. The expression of muscle PPAR $\gamma$ protein was not significantly changed by $3 \mathrm{~h}$ of insulin infusion $(300 \mathrm{mU}$. $\mathrm{m}^{-2} \cdot \mathrm{min}^{-1}$ ) from baseline values. They remained similar in the two groups (diabetic: $144 \pm 20$, non-diabetic: $146 \pm 14 \mathrm{AU} / \mu \mathrm{g}$ protein, post-clamp, see Table 2 for baseline values). The $\operatorname{PPAR} \gamma$ protein was also unaltered after insulin infusion, (diabetic, $107 \pm 7$, non-diabetic: $107 \pm 13 \mathrm{AU} / \mu \mathrm{g}$ protein, postclamp).

Protein expression of mFABP was also not significantly different after the clamp in both subjects with diabetes ( $206 \pm 30 \mathrm{vs} 224 \pm 11 \mathrm{pmol} / \mathrm{mg}$ protein, baseline vs clamp, respectively) and non-diabetic subjects (195 \pm 17 vs $207 \pm 16$ ). The protein expression of the muscle marker, $\alpha$-sarcomeric actin, was not influenced by short-term insulin exposure in either diabetic or non-diabetic subjects (not shown).

\section{Discussion}

A number of recent reports support roles for PPAR $\alpha$ and PPAR $\gamma$ in the regulation of glucose and lipid metabolism $[2,4-8,14-19]$. Although $\operatorname{PPAR} \beta$ is detectable in a wide range of tissues [11], including skeletal muscle and fat, it has not yet been assigned a specific role, partly due to its ubiquitous expression. For PPAR $\alpha$, investigators have focused their attention primarily on the liver, the tissue where PPAR $\alpha$ was described to be predominantly expressed in rat [11]. There is, however, also information indicating that the relative expression of PPAR $\alpha$ mRNA in human skeletal muscle is much higher than in rodent skeletal muscle [3]. Although the focus of research is widening to other cell types such as adipocytes, where PPAR $\alpha$ is up-regulated in hyperleptinaemia-induced adipocyte dedifferentiation [35], the role of PPAR $\alpha$ in skeletal muscle has not yet been addressed. The high expression of PPAR $\alpha$ protein in muscle relative to fat reported here $(7.6: 1)$, suggests that this nuclear protein could have an important role in muscle fatty acid metabolism.

The PPAR $\gamma$ protein is expressed early during adipocyte differentiation [36]. Several lines of evidence suggest an involvement of PPAR $\gamma$ in insulin action. There is a close relation between the antidiabetic, insulin-sensitising actions of the thiazolidinedione agents and their ability to bind to [18] and activate $\operatorname{PPAR} \gamma$ [1, 14-17, 36, 37]. Adipose tissue PPAR $\gamma$ mRNA is positively correlated with obesity (BMI) 
and insulin concentrations [21-24]. Weight loss leads to reductions in PPAR $\gamma$ expression in adipocytes, together with improvement in glycaemia and lipidaemia [21]. The majority of these observations were made in adipose tissue, yet PPAR $\gamma$ action in skeletal muscle could differ from that in the adipocyte. We [22] and others [12, 20, 21] have identified PPAR $\gamma$ mRNA in skeletal muscle, although in lower abundance than in adipose tissue and investigated its regulation and possible involvement in insulin action.

In this study we focused our attention on protein expression because it is the protein that is responsible for the gene effects of PPAR $\gamma$. Given the abundance of PPAR $\gamma$ in adipose tissue [20-22], a key concern is that the current results obtained in skeletal muscle could be influenced by the presence of adipose tissue in the biopsy samples. The following factors indicate that the contribution of adipose tissue to our results is limited. Neither mRNA, nor protein of the adipocyte specific gene $A L B P$ was detectable in muscle biopsy specimens, indicating that the adipose content was below the detection sensitivity of these methods. If a higher adipose tissue content did contribute to differences in the PPAR $\gamma$ protein abundance detected, then muscle biopsy samples from obese subjects could be expected to have a higher PPAR $\gamma$ protein content. In the analysis done on the subgroups, lean non-diabetic subjects have more muscle PPAR $\gamma$ protein than obese non-diabetic subjects who would be expected to have more fat in their muscle. Another point to note is the different mobilities of PPAR $\gamma$ protein detected in the two tissues. The results of our PPAR $\gamma 2$ blots suggest that the larger form seen in adipose tissue is most likely the $\gamma 2$ isoform. This band is not apparent in the muscle samples but it should be there if appreciable contamination by adipose tissue were present.

Although PPAR $\gamma$ protein expression was similar in the total diabetic and non-diabetic groups, diabetic subjects with severe insulin resistance (GDR $=3-6$ ) had a significantly higher $\operatorname{PPAR} \gamma$ protein compared to their more insulin sensitive counterparts matched with them for age and weight with and without diabetes (GDR =6-9). Diabetic and non-diabetic subjects of intermediate insulin responsiveness $(\mathrm{GDR}=6-9)$ were matched for BMI and have equal amounts of $\operatorname{PPAR} \gamma$ protein. The most insulin resistant diabetic subjects (GDR $=3-6)$ were matched for BMI with both intermediate groups yet have the highest PPAR $\gamma$ protein, indicating that the key characteristic is the degree of insulin resistance and not obesity.

The increased expression of skeletal muscle PPAR $\gamma$ protein in Type II diabetic subjects with the most severe insulin resistance could reflect either an acquired or inherited abnormality. We did not find any direct relation between metabolic variables that are characteristically increased in Type II diabetes such as glucose, insulin or lipid concentrations, and PPAR $\gamma$ protein expression. Whether other factors unique to the metabolic environment of the diabetic state are involved in the regulation of expression or function of PPAR $\gamma$ protein in diabetes is still to be resolved. Functionally active mutations in the $P P A R \gamma$ gene, as possibly present in these severely insulin resistant subjects with Type II diabetes, could influence the function of the protein and lead to the abundance of PPAR $\gamma$ as observed in these patients. It should be remembered that the final action of $\operatorname{PPAR} \gamma$ is dependent on a number of factors. These include, but are not limited to, the expression and function of PPAR $\gamma$, the abundance of the relevant endogenous ligands/activators, numerous co-activators or co-repressors and the expression and function of RXRs, the companion nuclear receptors essential for formation of the active heterodimeric complex [1].

We have previously shown that insulin infusion rapidly increases PPAR $\gamma$ mRNA expression in muscle [22]. That protein expression of any PPAR was not up-regulated after $3 \mathrm{~h}$ of insulin exposure could be due to translational kinetics which do not permit complete synthesis and processing of detectable additional quantities of the proteins in that time. In agreement with our previous finding in muscle, a recent report also found PPAR $\gamma$ mRNA in adipose tissue to be increased after a 3-h hyperinsulinaemic, euglycaemic clamp [38]. Other investigators found no change in skeletal muscle PPAR $\gamma 1 \mathrm{mRNA}$ after $5 \mathrm{~h}$ of hyperinsulinaemia [39]. This discrepancy could also represent a potential transient nature of the insulin effect to increase gene expression, it could have returned to baseline by $5 \mathrm{~h}$. There are other examples of such transient responses in gene expression to insulin exposure [40].

Several conclusions can be drawn from the current work. First, the PPAR proteins are all expressed in skeletal muscle and adipose tissue but with distinct patterns. Since in vivo activation of PPAR $\gamma$ seems to influence both glucose and lipid concentrations whereas PPAR $\alpha$ agonists influence triglyceride metabolism [41], these receptors could be regulating different but complementary events in skeletal muscle. As ligands that activate PPAR $\beta$ have no effect on glucose or lipid concentrations [41], the role for PPAR $\beta$ in skeletal muscle is still uncertain. Of these three nuclear receptors, only skeletal muscle PPAR $\gamma$ shows differences between groups, with high protein expression in the most severely insulin resistant subjects. Furthermore, the relation between $\operatorname{PPAR} \gamma$ protein expression in skeletal muscle and peripheral insulin action/glucose disposal, either as a cause or a consequence, is altered in Type II diabetic compared with non-diabetic subjects. This suggests diabetes-related differences in the function or regulation of the PPAR $\gamma$ system in skeletal muscle. No such relation appears to exist for PPAR $\alpha$ protein. Thus, PPAR $\gamma$ 
content in skeletal muscle could be an important factor through which insulin controls glucose and lipid metabolism.

Acknowledgements. This work was supported by funds from Parke-Davis Co., the Whittier Institute for Diabetes Research, Medical Research Service, Department of Veterans Affairs and Veteran Affairs Medical Centre, San Diego and grant MO1 RR-00827 from the General Clinical Research Branch, Division of Research Resources, National Institutes of Health. Dr. Loviscach is the recipient of an American Diabetes Association Mentor-based Fellowship Award.

\section{References}

1. Schoonjans K, Staels B, Auwerx J (1996) The peroxisome proliferator activated receptors (PPARs) and their effects on lipid metabolism and adipocyte differentiation. Biochim Biophys Acta 1302: 93-109

2. Auverx J (1999) PPAR gamma, the ultimate thrifty gene. Diabetologia 42: 1033-1049

3. Su J, Simmons CJ, Wisely B, Ellis B, Winegar DA (1998) Monitoring of PPAR alpha protein expression in human tissue by the use of PPAR alpha-specific MAbs. Hybridoma 17: 47-53

4. Staels B, Dallongeville J, Auverx J, Schoonjans K, Leitersdorf E, Fruchart J (1998) Mechanism of action of fibrates on lipid and lipoprotein metabolism. Circulation 98: 2088-2093

5. Staels B, Auverx J (1998) Regulation of apo A-1 gene expression by fibrates. Atherosclerosis 137: [Suppl] S19-S23

6. Djouadi F, Weinheimer CJ, Saffitz JE, Pitchford C, Bastin J, Gonzalez FJ (1998) A gender-related defect in lipid metabolism and glucose homeostasis in peroxisome proliferator-activated Receptor $\alpha$-deficient mice. J Clin Invest 102: 1083-1091

7. Meertens LM, Miyata KS, Cechetto JD, Rachubinski RA, Capone JP (1998) A mitochondrial ketogenic enzyme regulates its gene expression by association with the nuclear hormone receptor PPAR $\alpha$. EMBO J 17: 6972-6978

8. Motojima K, Passilly P, Peters JM, Gonzalez FJ, Latruffe N (1998) Expression of putative fatty acid transporter genes are regulated by peroxisome proliferator-activated receptor $\alpha$ and $\gamma$ activators in a tissue- and inducer-specific manner. J Biol Chem 273: 16710-16714

9. Shalev A, Siegrist-Kaiser CA, Yen PM et al. (1996) The peroxisome proliferator activated receptor $\alpha$ is a phosphoprotein: regulation by insulin. Endocrinology 137: 4499-4502

10. Braissant O, Foufelle F, Scotto C, Dauça M, Wahli W (1996) Differential expression of peroxisome proliferatoractivated receptors (PPARs): tissue distribution of PPARalpha, -beta, and -gamma in the adult rat. Endocrinology 137: 354-366

11. Saltiel AR, Olefsky JM (1996) Thiazolidinediones in the treatment of insulin resistance and type II diabetes. Diabetes 45: 1661-1669

12. Elbrecht A, Chen Y, Cullinan CA et al. (1996) Molecular cloning, expression and characterization of human peroxisome proliferator activated receptors gamma 1 and gamma 2. Biochem Biophys Res Commun 224: 431-437

13. Forman BM, Tontonoz P, Chen J, Brun RP, Spiegelman BM, Evans RM (1995) 15-Deoxy-delta 12, 14-prostaglandin $\mathrm{J} 2$ is a ligand for the adipocyte determination factor PPAR gamma. Cell 83: 803-812
14. Krey G, Braissant O, L'Horset F et al. (1997) Fatty acids, eicosanoids, and hypolipidemic agents identified as ligands of peroxisome proliferator-activated receptors by coactivator-dependent receptor ligand assay. Mol Endocrinol 11: 779-791

15. Forman BM, Chen J, Evans RM (1996) The peroxisome proliferator-activated receptors: ligands and activators. Ann NY Acad Sci 804: 266-275

16. Pearson SL, Cawthorne MA, Clapham JC et al. (1996) The thiazolidinedione insulin sensitiser, BRL 49653, increases the expression of PPAR-gamma and aP2 in adipose tissue of high-fat-fed rats. Biochem Biophys Res Commun 229: 752-757

17. Berger J, Bailey P, Biswas C et al. (1996) Thiazolidinediones produce a conformational change in peroxisome proliferator-activated receptor-gamma: binding and activation correlate with antidiabetic actions in $\mathrm{db} / \mathrm{db}$ mice. Endocrinology 137: 4189-4195

18. Lehmann JM, Moore LB, Smith-Oliver TA, Wilkison WO, Willson TM, Kliewer SA (1995) An antidiabetic thiazolidinedione is a high affinity ligand for peroxisome proliferator-activated receptor gamma (PPAR gamma). J Biol Chem 270: 12953-12956

19. Reginato MJ, Bailey ST, Krakow SL et al. (1998) A potent antidiabetic thiazolidinedione with unique peroxisome proliferator-activated receptor $\gamma$-activating properties. J Biol Chem 273: 32679-32684

20. Fajas L, Auboeuf D, Raspe E et al. (1997) The organization, promoter analysis, and expression of the human PPAR gamma gene. J Biol Chem 272: 18779-18789

21. Vidal-Puig AJ, Considine RV, Jimenez-Linan $M$ et al. (1997) Peroxisome proliferator-activated receptor gene expression in human tissues. Effects of obesity, weight loss, and regulation by insulin and glucocorticoids. J Clin Invest 99: 2416-2422

22. Park KS, Ciaraldi TP, Abrams-Carter L, Mudaliar S, Nikoulina SE, Henry RR (1997) PPAR-gamma gene expression is elevated in skeletal muscle of obese and type 2 diabetic subjects. Diabetes 46: 1230-1234

23. Vidal-Puig A, Jimenez-Linan M, Lowell BB et al. (1996) Regulation of PPAR gamma gene expression by nutrition and obesity in rodents. J Clin Invest 97: 2553-2561

24. Lefebvre AM, Laville M, Vega N et al. (1998) Depot-specific differences in adipose tissue gene expression in lean and obese subjects. Diabetes 47: 98-103

25. Zierath JR, Ryder JW, Doebber Tet al. (1998) Role of skeletal muscle in thiazolidinedione insulin sensitiser (PPAR gamma agonist) action. Endocrinology 193: 5034-5041

26. Yost TJ, Eckel RH (1992) Regional similarities in the metabolic regulation of adipose tissue lipoprotein lipase. Metabolism 41: 33-36

27. Thorburn AW, Gumbiner B, Bulacan F, Brechtel G, Henry RR (1991) Multiple defects in muscle glycogen synthase activity contribute to reduced glycogen synthesis in non-insulin dependent diabetes mellitus. J Clin Invest 87: 489-495

28. Report of the Expert Committee on the Diagnosis and Classification of Diabetes Mellitus (1997) Diabetes Care 20: $1183-1197$

29. Henry RR, Abrams L, Nikoulina S, Ciaraldi TP (1995) Insulin action and glucose metabolism in nondiabetic control and NIDDM subjects. Comparison using human skeletal muscle cell cultures. Diabetes 44: 936-946

30. Burnette WN (1981) "Western blotting": electrophoretic transfer of proteins from sodium dodecyl sulfate-polyacrylamide gels to unmodified nitrocellulose and radiographic detection with antibody and radioiodinated protein A Anal Biochem 112: 195-203 
31. Bradford MM (1976) A rapid and sensitive method for the quantitation of microgram quantities of protein utilizing the principal of protein-dye binding. Anal Biochem 71: 248-254

32. Fajas L, Auboef D, Raspe E et al. (1997) The organization, promoter analysis, and expression of the human PPAR $\gamma$ gene. J Biol Chem 272: 18779-18789

33. Paulussen RJ, Geelen MJH, Beynen AC, Veerkamp JH (1989) Immunochemical quantitation of fatty-acid-binding proteins. Tissue and intracellular distribution, postnatal development and influence of physiological conditions on rat heart and liver FABP. Biochim Biophys Acta 1001: 201-209

34. Cox RD, Garner I, Buckingham ME (1990) Transcriptional regulation of actin and myosin genes during differentiation of a mouse muscle cell line. Differentiation 43: 183-191

35. Zhou YT, Wang ZW, Higa M, Newgard CB, Unger R (1999) Reversing adipocyte differentiation: implications for treatment of obesity. Proc Natl Acad Sci USA 96: 2391-2395

36. Brun RP, Spiegelman BM (1997) PPAR gamma and the molecular control of adipogenesis. J Endocrinol 155: 217-218
37. Spiegelman BM (1998) PPAR- $\gamma$ : adipogenic regulator and thiazolidinedione receptor. Diabetes 47: 507-514

38. Rieusset J, Andreelli F, Auboeuf D et al. (1999) Insulin acutely regulates the expression of the peroxisome proliferator-activated receptor- $\gamma$ in human adipocytes. Diabetes 48: 699-705

39. Kruszynska YT, Mukherjee R, Jow L, Dana S, Paterniti JR, Olefsky JM (1998) Skeletal muscle peroxisome proliferator-activated receptor- $\gamma$ expression in obesity and non-insulin-dependent diabetes mellitus. J Clin Invest 101: 543-548

40. Crettaz M, Muller-Wieland D, Kahn CR (1988) Transcriptional and posttranscriptional regulation of tyrosine aminotransferase by insulin in rat hepatoma cells. Biochemistry 27: 495-500

41. Berger J, Leibowitz MD, Doebber TW et al. (1999) Novel peroxisome proliferator-activated receptor (PPAR) gamma and PPARdelta ligands produce distinct biological effects. J Biol Chem 274: 6718-6725 